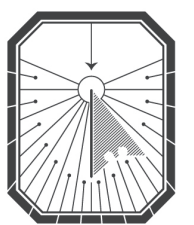

KYIV-MOHYLA

LAW \& POLITICS JOURNAL

KYIV-MOHYLA SCHOLARLY PEER-REVIEWED JOURNALS

The Comparative Analysis of Regional Governors' Approaches to Fostering Inclusive Political Institutions in Post-Euromaidan Donbas

Author(s): Valentyna Romanova

Source: Kyiv-Mohyla Law and Politics Journal 3 (2017): 71-89

Published by: National University of Kyiv-Mohyla Academy

http://kmlpj.ukma.edu.ua/ 


\title{
The Comparative Analysis of Regional Governors' Approaches to Fostering Inclusive Political Institutions in Post-Euromaidan Donbas
}

\author{
Valentyna Romanova \\ National University of Kyiv-Mohyla Academy; \\ Institute for Strategic Studies "New Ukraine"
}

\begin{abstract}
This study is inspired by a theory-driven expectation of a co-author of Why Nations Fail Daren Acemoglu in regard to fostering inclusive political institutions in post-Euromaidan Ukraine despite the armed conflict in Donbas. I examine how appointing a civil society activist - the one who used to help the Ukrainian Army during the security operation in Donbas — for a position of a regional executive in post-Euromaidan Luhansk oblast affects regional governors' approaches towards the key conditions of inclusive political institutions: state capacity and power distribution. State capacity, namely its key dimension of monopoly over violence, is operationalized as control over the contact line in the armed conflict in Donbas. Power distribution is operationalized as holding democratic elections. I compare the approaches of three regional executives, including the one who was the civil society activist, towards state capacity and power distribution. I find that appointing the civil society activist for a position of a regional executive in post-Euromaidan Luhansk oblast affects regional governors' approach towards control over the contact line, but not towards holding democratic elections. The study contributes to literatures on inclusive political institutions by analyzing new empirical data in line with the conceptual framework of Acemoglu and Robinson tailored for its application in post-Euromaidan Luhansk oblast.
\end{abstract}

Key Words: inclusive political institutions, Ukraine, Luhansk oblast, regional executives, civil society.

\section{讨}

\section{Introduction}

Co-author of Why Nations Fail ${ }^{1}$ Daren Acemoglu claims that, after the Euromaidan and despite the armed conflict in Donbas, Ukraine obtained a new chance to promote inclusive political institutions. ${ }^{2}$ Acemoglu and Robinson explain that inclusive political institutions, where institutions are understood as rules, have two conditions: "a state with capacity and a broad

1 Daron Acemoglu and James Robinson, Why Nations Fail: The Origins of Power, Prosperity, and Poverty (New York: Crown Publishers, 2012).

2 Daron Acemoglu, "Ukraine’s Legacy of Serial Oligopoly, “The Globe and Mail, March 14, 2014, accessed May 31, 2017, http://www.theglobeandmail.com/opinion/ukrainians-need-inclusion-not-extraction/ article17481308/. 
distribution of political power." ${ }^{3}$ Acemoglu and Robinson state that increasing state capacity and improving power distribution are closely connected to "the coevolution of the state and society." Acemoglu argues that Ukraine had already wasted two chances to establish inclusive institutions: after the collapse of the USSR and after the Orange revolution. He expects post-Euromaidan Ukraine to benefit from new opportunities to promote inclusive political institutions despite the armed conflict in Donbas. ${ }^{5}$

In this study civil society is understood as a social space outside governmental, businessoriented, and family relationships and activities, where individuals come together voluntarily to advocate their common interests. ${ }^{6}$ Civil society entities may include civil society organizations and citizen activist groups that consist from civil society activists. ${ }^{7}$ In post-Euromaidan Ukraine, civil society activists — either individually, or via civil society organizations — often contribute to work on conflict-related issues. Civil society activists provide assistance to Ukrainian regular military units and voluntary military units that fight in the conflict zone. ${ }^{8}$ For example, civil society activists initiate fundraising activities in order to purchase and transport food, warm clothes, medical items, etc. to military personnel. There is an important distinction: while civil society activists assist the regular military units or voluntary military units (battalions), they do not fight, unlike voluntary military units, which were formed soon after the outbreak of the armed conflict in 2014, when the Ukrainian Army was not able to carry out its functions during the security operation in Donbas launched by the Ukrainian government in the eastern Ukraine on April 14, 2014 (the "Anti-Terrorist Operation"). By September 2014, there were 44 voluntary military units of territorial defense within the Ukrainian Army, 32 police voluntary military units, and 3 special voluntary military units within the National Guard. 37 voluntary military units out of them fought in Donbas. By the end of 2015, most (not all) voluntary military units were integrated into the Ukrainian Army and the National Guard. In post-Euromaidan Ukraine, a civil society activist is most often labeled as volonter, while a member of voluntary military unitsdobrovolets.

In post-Euromaidan Luhansk oblast, a civil society activist who used to help the Ukrainian Army during the security operation in Donbas was appointed to a position of a regional

Daron Acemoglu and James Robinson, "Paths to Inclusive Political Institutions," January 16, 2016, accessed May 31, 2017, https://economics.mit.edu/files/11338.

4 Acemoglu and Robinson, "Paths to Inclusive Political Institutions."

5 Acemoglu, "Ukraine's Legacy of Serial Oligopoly."

6 National and International Mechanisms of Funding Civil Society. International Practices on ConfidenceBuilding Measures between the State and Civil Society, accessed July 20, 2017, http://www.osce.org/ ukraine/86185?download=true.

7 Maksym Latsyba, Government Policy and the Level of Development of Civil Society in Ukraine (Kyiv: Ukrainian Centre for Independent Political Research, 2006).

8 OSCE Special Monitoring Mission to Ukraine, Civil Society and the Crisis in Ukraine: Thematic Report, March 4, 2015, 5, accessed July 20, 2017, http://www.osce.org/ukraine$\mathrm{smm} / 141046$ ?download=true. 
executive ${ }^{9}$ - a key position for agenda-setting and decision-making in the region..$^{10}$ No similar appointments happened before Euromaidan. In the manuscript, this phenomenon is defined as "civil society inclusion in public administration." previous engagement in civil society activism affects the approaches of a regional governor during his or her tenure in office - in comparison with the approaches of other regional governors appointed to serve in the same region after Euromaidan.

Although the conceptual framework of inclusive political institutions suggests no specific formulas of "coevolution of the state and society," ${ }^{12}$ it still allows making the first step to apply the concept of inclusive political institutions to post-Euromaidan Ukraine. This study explores how appointing civil society activist who used to help the Ukrainian Army during the security operation in Donbas to a top position in a regional state administration in post-Euromaidan Luhansk oblast affects regional governors' approaches towards improving state capacity and power distribution. It employs a small-N comparative analysis, specifically the most similar system design. The study largely relies on a dataset "Political Elites in Ukrainian Regions" that includes data on the heads of regional assemblies and the heads of regional public administrations. ${ }^{13}$

The article starts from reviewing literature on inclusive political institutions and tailors the analytical framework based on the conceptual approach suggested by Acemoglu and Robinson ${ }^{14}$ and modified for the analytical purposes of this qualitative study in order to answer the research question. Then it analyzes and compares the empirical data. Finally, it concludes and suggests further research agenda.

\section{The Framework for Analysis}

In Why Nations Fail Daren Acemoglu and James Robinson claim that the success of nations depends on the type of institutions understood as "rules that govern and shape economic and

9 A regional executive means a regional governor, or the head of regional public (military-civil) administration.

10 A "region" means an oblast — an administrative-territorial unit at a sub-state level, listed in the Constitution.

11 In post-Euromaidan Ukraine, there are cases when civil society activists, especially those who help the Ukrainian Army during the security operation in Donbas, are appointed to serve in or elected to regional and sub-regional authorities. For example, Semen Salatenko, who used to be a civil society activist engaged in cultural and historical projects in Sumy oblast as a volonter and also joined the voluntary military unit "Dnipro-1" as a dobrovolets (2014-2015), was the head of Sumy regional council (December 4, 2015 - December 2, 2016). The deputy head of Zaporizhzhia regional council Yehor Semenkov (November 2015 - till now) used to be a civil society activist who helped the Ukrainian Army and voluntary military units during the security operation in Donbas.

12 Acemoglu and Robinson, "Paths to Inclusive Political Institutions."

13 The dataset is hosted by Hokkaido University (Japan) and is currently being updated. This article cites the sources used in it.

14 Acemoglu and Robinson, Why Nations Fail; Acemoglu and Robinson, "Paths to Inclusive Political Institutions." 
political life."15 Their understanding of institutions goes in line with the neo-institutionalist approach, according to which institutions are regarded as "the rules of the game," and contrasts to the approach of Dahl, who understands institutions as organizations. ${ }^{16}$ The concept of Acemoglu and Robinson highlights the interplay between political and economic institutions: political institutions determine economic ones, because political institutions affect the extent to which economic benefits are concentrated in the hands of few or spread among the country's citizens. ${ }^{17}$ This article focuses on political institutions.

Robinson and Acemoglu classify political and economic institutions into two types: inclusive and extractive. Extractive political institutions avoid sharing responsibilities and fail to provide basic public services the state is responsible for, instead rent seeking and corruption can flourish; in turn, inclusive political institutions allow incorporating many actors into decision-making and ensure that the state provides key public goods to its citizens, including the rule of law and equal access to public services. ${ }^{18}$ While extractive political institutions are designed to narrow down the opportunities of providing public goods to people, "[m] ost successful countries fall into the camp of inclusive societies, where political power and economic benefits are shared broadly among the population." 19 Inclusive political institutions largely contribute to the success of democratic nations, extractive institutions lead to nations' failure. The limitations of the concept of Robinson and Acemoglu come from the lack of a precise definition of inclusive political institutions. ${ }^{20}$ Thus, some scholars claim that the understanding of what is "inclusive" and what is "extractive" tends to depend on the actual outcomes (or results) of particular policies. ${ }^{21}$

Acemoglu and Robinson identify two conditions of inclusive political institutions: state capacity and the distribution of power. By the distribution of power, they mean "making political power more broadly based in society," whereas by state capacity they mean that "the state develops some basic attributes, a monopoly over violence, a bureaucratic administration and fiscal system, and has the 'capacity' to provide public goods and regulate society and enforce laws." 22 Acemoglu and Robinson stress that inclusive political institutions emerge from "the coevolution of the state and society" and emphasize that public involvement into decision-making largely contributes to "a balanced increase in state capacity and the distribution of power." 23

Huntington suggested a different logic of interplay between state capacity and the distribution of power; he claims that the political development of a state can lead to a broad

15 scholar.harvard.edu/jrobinson/presentations/why-regions-fail-mexican-case.

16 Robert Dahl, Democracy and Its Critics (New Haven; London: Yale University Press, 1989).

17 Acemoglu and Robinson, Why Nations Fail, 46o.

18 Robinson, "Why Region Fail."

19 Acemoglu, "Ukraine's Legacy of Serial Oligopoly."

20 Acemoglu and Robinson, Why Nations Fail, 368-403.

21 Michele Boldrin, David Levine and Modica Salvatore, "Review of Acemoglu and Robinson's Why

Nations Fail," Book Review, September 2012, accessed May 31, 2017, http://blogs.exeter.ac.uk/ insted/2013/o4/og/why-nations-fail-the-origins-of-power-prosperity-and-poverty/. Acemoglu and Robinson, "Paths to Inclusive Political Institutions." 
distribution of power. ${ }^{24}$ Huntington's logic should be understood in the context of his broader investigation on the interplay between democracy and state capacity: if there is no state capacity, political destabilization is inevitable. ${ }^{25}$ Acemoglu and Robinson agree that "it is difficult to create more state capacity and to make political power more broadly based in society at the same time"; however, they claim that successful democratic nations with inclusive political institutions managed to do so. ${ }^{26}$

The concept of inclusive versus extractive institutions has been applied to regions. Robinson studies the differences between regions in a country and for identifying the move towards inclusive political institutions at federal and state levels in Mexico. ${ }^{27}$ Thus, Robinson employs a region as a unit of analysis, as suggested by Jeffery and Wincott who justify studying territorial politics "on its own right," rather than uses a nation-state as a unit of analysis in this study. ${ }^{28}$

This article investigates appointing a civil society activist, who used to help the Ukrainian Army, on the position of a regional executive as a matter of civil society inclusion to regional public administration in post-Euromaidan Luhansk oblast. It seeks to understand if the background of the civil society activist, with the special focus on security matters in post-Euromaidan Donbas, affects the approaches of the regional governor towards control over the contact line and towards holding democratic elections. The experience of civil society activism, especially in the area of security matters in the conflict-torn Donbas, might affect the policy-makers priorities while agenda-setting and decision-making. A regional executive, who used to act as a civil society activist, might have gained an experience of cooperating with his or her peers and, therefore, might have good reasons to trust them later on. Such a regional governor might be ready to rely on the previously established networks of civil society activists. Instead, regional governors without such an experience might have little reasons to trust civil society activists and groups, especially when it comes to security matters. In post-Euromaidan Kyiv and regions, civil society activists get incorporated into public authorities; therefore, it is useful to understand if and how their background affects the way they carry out their duties.

The research question of this study is as follows: How does civil society inclusion to regional public administration affect regional governors' approaches towards state capacity and power distribution in post-Euromaidan Luhansk oblast?

The independent variable is civil society inclusion, operationalized as appointing a civil society activist who used to help the Ukrainian Army to the position of a regional executive. Dependent variables are state capacity and power distribution. By state capacity Acemoglu and Robinson mean that "the state develops some basic attributes, a monopoly over violence, a bureaucratic administration and fiscal system, and has the 'capacity' to provide public goods and

24 Samuel Huntington, Political Order in Changing Societies (New Haven; London, Yale University Press, 1968).

25 Samuel Huntington, Political Order in Changing Societies, 399.

26 Robinson, "Why Region Fail."

27 Robinson, "Why Region Fail."

28 Charlie Jeffery and Daniel Wincott, "The Challenge of Territorial Politics: Beyond Methodological Nationalism," in New Directions in Political Science: Responding to the Challenges of an Interdependent World, ed. Hay Colin, (New York: Palgrave Macmillan, 2010), 177. 
regulate society and enforce laws." ${ }^{29}$ For the purposes of this study (and also bearing in mind the armed conflict in Donbas), I chose to prioritize the following dimension of state capacitya monopoly over violence, in line with its classic understanding by Weber that prioritizes the capacity of the state to successfully claim monopoly over the legitimate use of force within a given territory. ${ }^{30}$ In this study, I operationalize it as control over the contact line between the government controlled territory of Luhansk oblast, on the one hand, and areas of Luhansk oblast temporarily beyond government control, on the other hand. ${ }^{31}$ Among the three main theories of power (pluralist, elitist, and Marxist), Acemoglu and Robinson chose the theory of pluralism that explains how power is distributed; in line with their understanding, the distribution of power results from participation (including participation in elections) according to the rule of law. ${ }^{32}$ For the purposes of this study, I operationalize the distribution of power as holding democratic elections (despite the military and security threats in Luhansk oblast). In this article, I refer to the early 2014 parliamentary elections; the 2015 local elections; and the 2016 by-elections of an MP in the electoral district No. 114 in Luhansk oblast.

This study employs a comparative method, in particular the most similar system design, which seeks to explain difference or similarity by using similar cases that differ from each other only in terms of the key variable. I am aware of the key limitation of the comparative method - the so called "Galton's Problem": identifying a relationship between two phenomena does not mean it is a causal relationship, because the observed outcome might be caused by some intervening variable(s). ${ }^{33}$ The most similar system design works with causal arguments that usually are correlational in nature. ${ }^{34}$ This study does not seek to prove that its independent variable explains dependent variables better than any other. This is relevant for the probabilistic approach in social sciences, which implies that "explanatory factors increase or decrease the likelihood of an outcome, rather than determine it." ${ }^{35}$ The specific comparative method employed

29 Acemoglu and Robinson, "Paths to Inclusive Political Institutions."

30 Max Weber, Economy and Society: An Outline of Interpretive Sociology (Berkley: University of California Press, 1978 [1921]).

The decree of the Cabinet of Ministers of Ukraine No. 1085-p of November 7, 2014 (updated by Decree No. 1276-p signed on December 2, 2015) and the decision of the national parliament of Ukraine No. 252-VIII approved on March 17, 2015 identify the list of towns and villages situated in the territories of Luhansk oblast temporarily beyond government control. All individuals, vehicles, etc. that cross the contact line are obliged to hold a special permit; no unregistered trade or movement is allowed.

32 Acemoglu and Robinson, "Paths to Inclusive Political Institutions."

33 Potential intervening variables in this study may include the priorities of the central authorities. Where relevant, I acknowledge this matter in the empirical part for the study.

Stela Garaz, "Exploring the Link between Power Concentration and Ethnic Minorities' Mobilization in Post Soviet Georgia, Moldova, and Ukraine” (PhD diss., Central European University, 2012). 
in this study is the cross-case analysis that allows making comparisons over time, across cases and between them. ${ }^{36}$

The study compares the approaches of three regional executives in post-Euromaidan Luhansk oblast towards improving state capacity and the distribution of power in order to identify the role of the variable of civil society inclusion to regional public administration. The cases are similar, because the identified regional governors work within the similar legal framework in the same oblast. One out of three regional executives was a civil society activist who used to help the Ukrainian Army before his appointment. The remaining two are his predecessor and his successor on the position of a regional executive. The three regional executives under consideration are listed below.

Hennadii Moskal, a former police general, was a regional governor in Luhansk oblast in September 18, 2014-July 20, 2015. He is an experienced public servant who served in public administration and internal affairs at national and regional level in Ukraine. He was familiar with Luhansk oblast, because he served as the head of Luhansk regional state administration after the Orange Revolution (November 2005-April 2006). By the time of his appointment on September 18, 2014, Moskal served as a Member of Parliament (MP) and was the deputy head of the parliamentary committee on the fight against the organized crime and corruption.

Heorgii Tuka was a regional governor on July 22, 2015 - April 29, 2016. Since Euromaidan and till his appointment, Tuka was a committed civil society activist. After the start of the security operation in Donbas he established and chaired an NGO "Narodnyi Tyl" involved into fundraising for the Ukrainian Army. "Narodnyi Tyl" was one of the initiators of the Ukrainian website "Myrotvorets" - a non-governmental initiative, backed by the authorities that later on disclosed private data of more than 4,0oo international and domestic journalists accredited by the Russia-backed self-proclaimed republics in Eastern Ukraine. Also, Tuka contributed to the project "Volunteer Revisor" that monitored the conditions of everyday life of the Ukrainian military units during the security operation.

Yurii Harbuz was appointed as a regional governor on April 29, 2016. By that time he was an MP elected in an electoral district No. 114 in Luhansk oblast as a result of the 2014 early parliamentary elections. In the parliament, Harbuz remained non-partisan and joined the fraction of Block Petra Poroshenka. After his appointment as a regional governor, he dropped his mandate. Earlier he was a deputy of Milove raion (subregional) assembly and the head of Milove raion administration in Luhansk oblast.

The key reasons why the position of a regional governor is under special consideration are as follows. Regional executives largely affect state capacity, electoral processes, and party politics. ${ }^{37}$ Regional executives in government-controlled Donbas are granted additional responsibilities

36 Matthew Miles and Michael Huberman, Qualitative Data Analysis: An Expanded Sourcebook (London: Sage Publications, 1994).

37 Kimitaka Matsuzato, "From Communist Boss Politics to Post-Communist Caciquismo: The MesoElite and Meso-Governments in Post-Communist Countries," Communist and Post-Communist Studies 34 (2001): 175-201. 
as the heads of regional military-civil administrations. ${ }^{38}$ Luhansk regional assembly does not function since the start of the security operation. It was not (re)elected during the 2015 local elections.

This research is limited to Luhansk oblast. I justify this in line with the research agenda of employing a region as a unit of analysis and investigating territorial politics "on its own right." ${ }^{39}$ Furthermore, Ukraine is often characterized as "a state of regions" 40 due to its regional peculiarities. In order to gain a nuanced understanding of politics in Ukraine in general, it is useful to carry out in-depth studies of politics in its regions. For example, Luhansk oblast has been distinctive due to high numbers of ethnic Russians and Russian-speakers, as well as a border with Russia. The region has a long-lasting legacy of public discontent, starting already from the early 199os. Due to the ongoing armed conflict in Donbas, Luhansk oblast is divided into two partsthe one controlled by the Ukrainian government, and the one beyond government control, - with approximately 29, ooo internally displaced people in government controlled Luhansk oblast. The security operation affects the extent to which Ukraine's obligations in regard to human rights, for example, can be fully fulfilled in the region. This study recognizes that the security operation can partially affect the interplay between state capacity and power distribution - the key dimensions of inclusive political institutions. This is evident from the way state capacity is operationalised in this study. Still, the fact that a civil society activist was appointed as a regional executive in Luhansk oblast in times of the security operation in Donbas suggests examining the grounds of fostering inclusive political institutions there. Also, Luhansk oblast remains a Ukrainian region, comparable with other regions which are not directly affected by the armed conflict. The political and legal framework is the same throughout Ukraine due to the same electoral rules, the electoral cycle, statewide parties (regional parties are prohibited in Ukraine), etc.

Thus, this section has made it clear that the study examines regional governors' approaches towards control over the contact line and holding democratic elections. This is appropriate for the purposes of answering the research question and for making the first step, to my knowledge, of applying the conceptual framework of inclusive political institutions to post-Euromaidan Ukraine.

\section{Regional Governors' Approaches Towards the Fight Against Smuggling across the Line of Contact}

Smuggling became a key issue in Donbas after the contact line was identified in the Minsk II Agreements in February 2015. In Luhansk oblast, the smuggling channel is claimed to be situated across the narrows of the Siverskyi Donets River, in the area of the villages of Triokhizbenka,

38 On March 5, 2015 the President approved the Law on regional military-civil administrations. Luhansk regional state administration was transformed into Luhansk regional military-civil administrations, and military officers and security officers were incorporated into it. 
Lobacheve and Lopaskyne. ${ }^{41}$ I find that the approaches of regional governors towards the fight against smuggling across the contact line differ in regard to engaging with either voluntary military units, or with civil society activists who seek to help the Ukrainian Army in Donbas. ${ }^{42}$

Only ex-civil society activist Tuka endorsed the establishment of mobile groups (or mobile brigades), which consisted not only of the representatives of various military and security services, but also of civil society activists who helped the Ukrainian Army. The first mobile groups were introduced by the President Petro Poroshenko in July 2015 after his meeting with civil society activists who helped the Ukrainian Army, including then civil society activist Tuka. The President highlighted that Tuka was among those civil society activists who were truly committed to Ukraine's national interests, as evidenced by his contribution to the assistance to the Ukrainian Army. The President identified the mobile groups as the means of public control to fight smuggling along the contact line. ${ }^{43}$ Mobile groups were empowered to check if vehicles that crossed the contact line had the necessary permits, to inspect them, to assign administrative fine, and even to sue the owners of such vehicles, when required. ${ }^{44}$

This study does not measure the efficacy of Tuka's approach towards the fight against smuggling. His own opinion in this regard was positive: he claimed to reduce the extent of smuggling in the region up to 70 per cent after six months in office. ${ }^{45}$ Still only on April 28 , 2016 Tuka announced that the court sentenced those accused in smuggling across the contact line. Unfortunately, two mobile groups came under attack while carrying out their duties. On 2 September 2015 one mobile group came under fire. Four soldiers were wounded; civil society activist Andrii Halushchenko and a representative of the State Fiscal Service were killed. Tuka claimed that the military from the 92nd Brigade were responsible for that tragedy. Military prosecutors arrested two soldiers from the 92nd Brigade; however, later they were released from

41 Oksana Grytsenko, "Lucrative Trade in War Zone Persists despite Blockade that Tries to Stop it," Kyiv Post, March 9, 2017.

42 In Introduction, I clarify the difference between voluntary military units, on the one hand, and civil society activists who seek to help the Ukrainian Army in Donbas, on the other hand. In this manuscript "civil society inclusion to regional public administration" refers only to the appointment of a civil society activist on a position of a regional executive. "Prezydent ta volontery hotuiut nastup na koruptsiiu ta kontrabandu v zoni ATO [President and Volunteers Get Ready to Fight Corruption and Smuggling in the Areas where the ATO Takes Place]," President of Ukraine Petro Poroshenko Official Website, July 6, 2015, accessed May 20, 2017, http:// www.president.gov.ua/news/prezident-ta-volonteri-gotuyut-nastup-na-korupciyu-ta-kontra-35610.

44 Diana Kuryshko, "Yak mobilni hrupy boriutsia z kontrabandoiu v ATO [How Do Mobile Groups Fight Smuggling during the ATO]," BBC Ukraine, September 23, 2015, accessed May 31, 2017, http://www. bbc.com/ukrainian/society/2015/o9/150921_ato_smuggling_dk. Iryna Holotiuk, "Heorgii Tuka: 'Ne vizhu ni chisto voennogo, ni chisto diplomaticheskogo resheniia konflikta na Donbasse' [Heorgii Tuka: 'I See no Purely Military, no Purely Diplomatic Solution to the Conflict in Donbas']," Fakty, April 29, 2016, accessed May 31, 2017, http://fakty.ua/216188-georgijtuka-ne-vizhu-ni-chisto-voennogo-ni-chisto-diplomaticheskogo-resheniya-konflikta-na-donbassedumayu-on-zatyanetsya-na-neskolko-let. 
custody. The investigation is still ongoing. ${ }^{46}$ In March 2016 another mobile group was attacked. Some observers claim that Tuka's contribution to the fight against smuggling along the contact line was controversial. 47

Unlike Tuka, Moskal openly argued that the involvement either of civil society activists eager to help the Ukrainian Army, or voluntary military units in the fight against smuggling could undermine the monopoly of the state on violence. ${ }^{48}$ Moskal accused the representatives of voluntary military units "Aidar," "Chernihiv," and "Tornado" in contributing to smuggling. ${ }^{49}$ Following Moskal's concerns, some of them were soon arrested and sued.

In order to effectively fight against smuggling, Moskal decided to block economic relations and trade with the territories of Luhansk oblast temporarily beyond government control. This decision was taken on May 12, 2015 - long before the President signed his Decree in respect to the blockade in February 2017. Moskal did not allow any vehicles, including cars, to cross the contact line. ${ }^{50}$ There were exceptions for cyclists, pedestrians, and the vehicles of international humanitarian organizations. Moskal criticized the decision of the central government to supply the breakaway regions with water and energy for free..$^{51}$ Meanwhile, Moskal acknowledged the necessity to purchase coal from the territories temporarily beyond government control.

46 "Novyi povorot v dele ob ubiistve Endriu [A New Turning Point in Andrew's Murder]," Comments. ua, January 14, 2017, accessed July 31, 2017, https://comments.ua/society/571547-noviy-povorot-deleubiystve-endryu.html.

47 Anastasiya Ringis, "Kontrabandisty vs. volontery. Komu meshaiut mobilnye hruppy po borbe s kontrabandoi? [Smugglers vs. Volunteers. Whom do Mobile Groups for Fighting Smuggling Disturb?]," Ukrainska Pravda, September 9, 2015, accessed May 20, 2017, http://www.pravda.com.ua/ rus/articles/2015/o9/9/7080668/.

48 "Holova Luhanskoi oblasnoi viiskovo-tsyvilnoi administratsii Hennadii Moskal zvernuvsia do Ministra VSU, nachalnika Heneralnoho shtabu ZSU, sekretaria RNBO Ukrainy, shchob rozzbroity bataliony 'Tornado' i ‘Chernihiv' [The Head of Luhansk Military-Civil Administration Hennadii Moskal Addressed the Minister on Military Affairs, the Head of the General Headquarters of the Ukrainian Army, Secretary of the National Security and Defense Council and asked them to disarm the battalions ‘Tornado’ and ‘Chernihiv'],” Luhansk Military-Civil Administration Official Website, June 18, 2015, accessed May 31, 2017, http://www.loga.gov.ua/oda/press/news/golova-luganskoyioblasnoyi-viyskovo-civilnoyi-administraciyi-gennadiy-moskal.

49 'Moskal pryznachyv sluzhbove rozsliduvannia z pryvodu zatrymanyh vahoniv batalyonom 'Tornado' [Moskal Initiated an Investigation in regard to Tornado's Act of Blocking Coaches]," Luhansk Military-Civil Administration Official Website, June 18, 2015, accessed May 31, 2017 http://www.loga. gov.ua/oda/press/news/moskal-priznachiv-sluzhbove-rozsliduvannya-z-privodu-zatrimanih-vagonivbatalyonom.

$5^{\circ}$ Decree of the Head of Luhansk Military-Civil Administration No. 173 "On the Additional Instructions Regarding Limiting the Move of Vehicles across the Line of Separation of the Sides," May 12, 2015, accessed May 30, 2017, http://ipress.ua/media/gallery/full/4/c/4cc78d83af93f9e8af3cef59719a68oe.jpg.

$5^{1} \quad$ Oksana Grytsenko, "A Look at Life in Luhansk Oblast's 'Tinderbox' with Region’s Leader," Kyiv Post+, November 14, 2014, accessed March 31, 2017, https://www.kyivpost.com/article/content/war-againstukraine/a-look-at-life-in-luhansk-oblasts-tinderbox-with-regions-leader-371768.html. 
Harbuz shifted his positions in regard to the trade blockade with the territory of Luhansk oblast temporarily beyond government control, which was initiated by civil society activists, veterans of the security operation in Donbas, and voluntary military units in December 2016. The declared objective of the blockade was the fight against smuggling along the contact line via blocking trade; however, the outcomes of the blockade were claimed to do little to reach that goal. ${ }^{52}$ In December 2016 the initiators started blocking trade across the contact line and appealed to pro-Russian and Russia-backed rebels to release hostages, etc. On January 25, 2017 veterans of the security operation in Donbas and voluntary military units, including battalion "Aidar," blocked the railway "Luhansk - Popasna" and blocked the movement of trains across the contact line. In February 2017 the same approach was applied to blocking roads. The blockade was supported by a number of MPs.

Initially Harbuz heavily criticized the blockade and its initiators. He even warned that the blockade would be a catastrophe for the functioning of electric stations all over Ukraine. ${ }^{53}$ Also, he highlighted the risks of damaging Ukraine's image for investors. However, after the President of Ukraine decided to block trade across the contact line according to his Decree No. 62/2017 of March 15, 2017, ${ }^{54}$ Harbuz highlighted his support to that decision.

Thus, while Moskal and Harbuz expected military and security services to take responsibility over fighting against smuggling and were concerned about cooperating with civil society activists and voluntary military units, an ex-civil society activist Tuka endorsed the establishment of mobile groups, which included civil society activists, and actively engaged them into the fight against smuggling.

\section{Regional Governors' Approaches towards Holding Democratic Elections}

For the sake of domestic and international legitimacy, it was essential to ensure the principles of free and fair political contestation in post-Euromaidan Ukraine, despite the armed conflict in Donbas. Two out three regional governors in Luhansk oblast doubted that holding elections was possible in the region during the security operation.

Moskal called for re-scheduling the 2014 parliamentary elections, expected to be held on October 26, 2014, at least in some areas of Luhansk oblast. ${ }^{55}$ After the elections were announced by the Central Electoral Committee (CEC), he claimed to do his best to ensure safe, free and fair

Grytsenko, "Lucrative Trade in War Zone Persists."

"Hubernator Luhanshchiny o Blockade ORDLO [Regional Governor of Luhansk Oblast talks about the Blockade of the Areas of Luhansk Oblast Temporarily beyond the Government Control]," Liga. Novosti, January 26, 2017, accessed May 30, 2017, http://news.liga.net/news/politics/14679271gubernator_luganshchiny_o_Blockade_orlo_tets_ostanutsya_bez_topliva.htm.

4 On March 15, 2017 President Petro Poroshenko signed the Decree No. 62/2017 to block trade with the temporarily occupied territories. The Decree approved the decision of the National Security and Defence of Ukraine of March 15, 2017 to stop the movement of goods across the contact line in Donetsk and Luhansk oblasts (apart from the vehicles of domestic and international humanitarian organizations).

Grytsenko, "A Look at Life in Luhansk Oblast's 'Tinderbox.” 
elections in the region. Finally, elections were held in 5 out of 11 electoral districts in Luhansk oblast. The CEC allowed voters in Luhansk oblast who had to temporarily leave their households to cast their ballots outside their areas of residence. Turnout in the region was low (32.87\%). There were numerous attempts to break the electoral process, especially in those areas of Luhansk oblast that were close to the contact line. For example, the functioning of election commissions in Luhansk oblast faced significant difficulties, including the inability to transfer ballots and intimidation of staff, as confirmed by the Office for Democratic Institutions and Human Rights (ODIHR) whose representatives observed the election.

Moskal openly expressed his concerns regarding those candidates and parties whom they considered responsible for the conflict in Donbas (i. e. the Party of Regions and the Opposition Block). His eagerness to re-schedule the 2014 parliamentary elections in Luhansk oblast was partially explained by his fears that those candidates and parties could not only stand, but also win elections in the regions. ${ }^{56}$

Like Moskal, Tuka called for postponing local elections in the region due to security concerns and due to the risk of the electoral success of the Opposition Block and its allies. Still, he followed the guidelines of the CEC after the 2015 local elections in Luhansk oblast were announced. ${ }^{57}$ Due to security threats, the CEC identified the list of local assemblies in government controlled Donbas where the local elections would not be held on October 25, 2015 (including $3_{1}$ local assemblies in Luhansk oblast). In Svatove (Luhansk oblast) elections to the city assembly were broken due to errors in ballots. Although there were formal institutional means for party competition during the 2015 local elections, fewer parties with shorter party lists run for the 2015 local elections in government-controlled areas of Luhansk oblasts. Voter turnout was low $(35.27 \%)$. According to the decision of the CEC, temporarily displaced persons were not allowed to cast their ballot outside the area of their official residence. The Mission of the Office for Democratic Institutions and Human Rights of the OSCE and the Congress of Local and Regional Authorities of the Council of Europe claimed that in general the elections in Ukraine met democratic standards.

Tuka acknowledged his opposition to the Party of Regions and the Opposition Block who enjoyed public support in the region. He openly criticized these political parties for being responsible of the armed conflict in Donbas. His straightforward and sometimes blunt criticism of politics in Ukraine during the current stage of democratisation can be explained by his lack of previous experience in party politics. In 2014 Tuka attempted to become an MP. During the 2014 early parliamentary elections he joined the party list of "Ukraine - the United Country" (No. 5). However, the party did not manage to win any seat in the national parliament: it scored only $0.12 \%$. Thus, Tuka had political ambitions; however, he demonstrated the lack of effective engagement in party politics and no links to influential interest groups.

Unlike Moskal and Tuka, Harbuz did not call for re-scheduling the by-election of an MP in the electoral district No. 114 in Luhansk oblast announced to be held on July 17, 2016. The electoral district No. 114 is situated near the contact line. Due to security concerns, the district electoral

56 Grytsenko, "A Look at Life in Luhansk Oblast's 'Tinderbox.”

57 The first round of the 2015 local election was held on October 25, 2015. The second round of local elections (in regard to city mayors) was held on November 15, 2015. 
committee worked not in Stanytsia Luhanska, as suggested by the CEC, but in Bilovodsk. The by-election was held in 133 out of 197 polling stations of the electoral district No. 114. According to the OSCE, on July 16-17, 2016 there were fewer cases of the violations of ceasefire in comparison to July $15,2017 .{ }^{58}$ Turnout was relatively high (63.07\%).

During the electoral campaign Harbuz called for a free and fair electoral contestation and publicly demonstrated his eagerness to ensure that the by-election was held according to the law. However, when the head of the district electoral committee, the representative of the Opposition Block Yevhen Bairamov was severely beaten on the eve of the by-election, Harbuz expressed his concerns in regard to the possibility of free and fair electoral contestation. Anyway, the byelection was finally held and widely recognized as legitimate, despite some concerns in regard to free and fair electoral contestation by international and domestic observers. The winner was Serhii Shakhov who represented a newly established political party called "Our Land" (Nash Krai). Some observers claimed that Shakhov was connected to the Party of Regions and the Opposition Bloc, while other analysts argued that he was supported by the President's Administration. In this context, some accused Harbuz in his loyalty to the Opposition Bloc, especially bearing in mind that after being appointed as a regional governor, he addressed the representatives of all political parties in the region and suggested to cooperate rather than compete with each other.59

Thus, while Harbuz did not attempt to re-schedule elections in the region, Moskal and Tuka recommended postponing elections in some areas in Luhansk oblast, preferably until the end of the security operation. Despite concerns, the elections were held (where possible) and recognized as legitimate.

\section{Analysis}

The approaches of regional governors towards control over the contact line in Luhansk oblast differ in terms of their attitude towards engaging with civil society activists and volunteer military units. Tuka's background as a civil society activist, who helped the Ukrainian Army, and his commitment to dealing primarily with the security matters seem to have inspired Tuka to call the fight against smuggling his key priority on a position of a regional governor in Luhansk oblast. It is likely that Tuka decided to engage mobile groups into the fight against smuggling, because of his previous cooperation with civil society activists who assisted the Ukrainian Army. Due to his own experience, he believed that civil society activists could contribute to rather than undermine the state's monopoly over violence. After Tuka's dismissal from the position of a regional executive, mobile groups were no longer engaged in the fight against smuggling. Namely

58 OSCE Special Monitoring Mission to Ukraine, Latest from OSCE Special Monitoring Mission (SMM) to Ukraine, Based on Information Received as of 19:30, July 17, 2016, accessed July 20, 2017, http://www. osce.org/uk/ukraine-smm/254811.

59 Serhii Maksymov, "Novyi hubernator Luhanshchiny podigryvaet OppoBloku—sluchainost ili zakonomernost? [New Regional Governor in Luhansk Oblast Helps OppoBlock—Fortuitousness or Pattern?]," Obozrevatel, May 30, 2016, accessed May 31, 2017, https://www.obozrevatel. com/blogs/82o94-novyij-gubernator-luganschinyi-podyigryivaet-oppoBlocku-sluchajnost-ilizakonomernost.htm. 
due to the ambiguous efficacy of mobile groups in regard to the fight against smuggling, Tuka's successor on the position of a regional executive-Harbuz - abolished mobile groups and their engagement into the fight against smuggling.

Moskal and Harbuz believed that involving civil society activists or voluntary military units could put state's monopoly over violence at risk. Tuka's predecessor — Moskal—claimed he did not need help of civil society activists or voluntary military units. He made his independent decision to block trade with the territories of Luhansk oblast temporarily beyond government control long before the President's decision. Moskal's declared objective and the chosen mechanism of the fight against smuggling were positively perceived by some MPs in the national parliament. Then the head of the parliamentary faction "Block Petra Poroshenka" Yurii Lutsenko positively characterized Moskal's decision and even suggested the national parliament to make a similar one. ${ }^{60}$

Tuka's successor - Harbuz - heavily criticized the attempts of civil society activists or voluntary military units to fight against smuggling via blocking trade with the territories oh Luhansk oblast beyond government control in late 2016 - early 2017. Harbuz openly warned about the negative consequences of the blockade, including the risk of putting state's monopoly over violence at risk. Only when the President decided to officially block trade with these territories, he supported that decision.

As for the elections under consideration, they were expected to ensure democratic proceedings in Ukraine; therefore, it was crucial to hold legitimate elections in Donbas. Despite some concerns, all three electoral contests were held (where possible in the region) and recognized as legitimate both domestically and internationally.

The analysis demonstrates that all three regional governors were eager to improve the conditions of holding democratic elections in Luhansk oblast, regardless of their previous experience in voluntary activities, public administration or electoral politics. Regional governors' approaches differ mainly in their attitudes to the need to hold elections under severe security threats.

Moskal and Tuka doubted that electoral contests were possible in the region with an armed conflict. Also, they were highly concerned that elections could strengthen the electoral positions of those party representatives whom they considered to be responsible for the armed conflict in Donbas in the first place (namely the Opposition Block). After the results of the 2015 local elections were announced, Tuka regretfully acknowledged that the Opposition Block won seats in local assemblies, but claimed that it lost a considerable share of its public support in the region. ${ }^{61}$ For example, in Lysychansk city council there are 24 Opposition Block representatives (out of 36 seats); there are 25 Opposition Block representatives in Rubizhne city council (out of 34); there are 16 Opposition Block representatives in Severodonetsk city council (out of 36 ).

60 “Lutsenko: Ekonomichna blokada 'DNR/LNR' neobhidna [Lutsenko: The Economic Blockade of 'DPR/LPR' is Necessary]," BBC Ukraine, June 8, 2015, accessed May 30, 2017,' http://www.bbc.com/ ukrainian/politics/2015/o6/15o6o8_lutsenko_ie_donbass_economic_blockade_sd.

$61 \quad$ Heorgii Tuka, "Vybory. Pershyi dosvid [The Election. The Very First Experience]," Censor.net, Tuka's Blog, October 26, 2015, accessed May 31, 2017, https://censor.net.ua/blogs/1135/vibori_pershiyi_dosvd_ quotzserediniquot. 
Moskal highlighted the electoral success of pro-Ukrainian parties that all together gained about a third of the votes in Luhansk oblast. ${ }^{62}$

None of regional governors stood for elections while in office, unlike in previous electoral contests in Ukraine. Harbuz and Moskal lost their mandates of MPs after being appointed to serve as regional governors in Luhansk oblast.

The study does not find convincing evidence that civil society inclusion to regional public administration affects the respective regional governors' approaches. The intensity of the armed conflict seems to affect the regional governors' approaches towards holding elections most of all. For example, by the time of Moskal's appointment as a regional executive and on the eve of the 2014 early parliamentary elections, the armed conflict was in an active stage, and a significant part of the region was beyond government control: nine out of 18 districts of the oblast.

The study highlights that "the coevolution of the state and society," as well as "a balanced increase in state capacity and the distribution of power" 63 should not be taken for granted. This notion brings back the suggestion of Huntington: "elections to be meaningful presuppose a certain level of political organization." ${ }^{64}$ This is exactly what regional governors in Luhansk oblast were arguing when explaining their concerns about holding elections in the region: first, due to security reasons; second, due to their unwillingness to provide additional institutional means for empowering the representatives of those political parties whom they considered responsible for the armed conflict in Donbas.

In my view, the cases under consideration prove the notion of Acemoglu and Robinson who claim that "it is difficult to create more state capacity and to make political power more broadly based in society at the same time." ${ }^{65}$ Despite security and other concerns, elections were held in some areas in Luhansk oblast, and this can be regarded as a step towards "a balanced increase in state capacity and the distribution of power." 66

\section{Conclusion}

The article was inspired by the expectation of Acemoglu that post-Euromaidan Ukraine obtained a new chance to promote inclusive political institutions despite the armed conflict in Donbas. ${ }^{67}$ Inclusive political institutions have two key conditions: state capacity and power distribution. Also, they are closely connected to "the coevolution of the state and society." 68

62 According to the electoral results in Luhansk oblast, the Opposition Block gained 36.59\%, or 53516 voters, Petro PoroshenkoBlock -14.32\%, or 2094 o voters, the Communist Party $-11.88 \%$, 17385 voters; Party of Serhii Tyhipko "Strong Ukraine" $-8.77 \%$, or 12825 voters; the People's Front (Narodnyi Front $)-5 \cdot 94 \%$, or 8695 voters, Radical Party of Oleh Liashko- $5 \cdot 36 \%$, or 7851 voters, Self-Help$5.14 \%$, or 7519 voters.

63 Acemoglu and Robinson, "Paths to Inclusive Political Institutions."

64 Huntington, Political Order in Changing Societies, 7.

65 Robinson, "Why Region Fail."

66 Acemoglu and Robinson."Paths to Inclusive Political Institutions."

67 Acemoglu, "Ukraine's Legacy of Serial Oligopoly."

68 Acemoglu, "Ukraine's Legacy of Serial Oligopoly." 
This article presents the results of a qualitative study that aimed at examining if and how appointing a civil society activist on a position of a regional executive in post-Euromaidan in Luhansk oblast affects regional governors' approaches towards state capacity (operationalized as control over the contact line) and power distribution (operationalized as holding democratic elections) in the region. The study compared the approaches of three regional governors who were appointed to serve in Luhansk oblast after the Euromaidan, including the one who was previously engaged into civil society activism.

The key finding is that only the regional governor with the background of civil society activism (Tuka) opened up institutional opportunities for civil society activists to contribute to the fight against smuggling via endorsing the establishment of seven mobile brigades and promoting their activities in Luhansk oblast. The mobile groups were identified as the means of public control to fight smuggling by President Poroshenko. Tuka's approach lasted as long as he served as a regional executive and did not constitute the lasting legacy. The study clams that Tuka's approach towards the fight against smuggling with the help of mobile brigades was largely determined by his background as a committed civil society activist. His voluntary initiatives before the appointment as a regional executive were aimed at improving the capacity of Ukrainian military units to properly carry out their duties during the security operation in Donbas. They seem to have largely determined his key priorities as a regional governor.

The comparative analysis of the approaches of regional governors in Luhansk oblast after the Euromaidan towards holding democratic elections demonstrates that the key difference refers to the necessity to either hold, or postpone elections. There were security concerns related to the armed conflict. Also, two regional governors (Tuka and Moskal) were concerned about the electoral perspectives of those candidates and parties whom they considered responsible for the armed conflict in Donbas. All three regional executives carried out their responsibilities in respect to holding democratic elections in the respective areas. The study does not find convincing evidence that civil society inclusion to regional public administration affects the respective regional governors' approaches. The stage of the armed conflict in the region during the electoral campaign is more likely to determine regional governors' approaches towards holding elections.

Thus, the article brought in timely empirical data on post-Euromaidan Luhansk oblast and examined it within the chosen analytical framework in order to address the theory-driven expectation of Acemoglu 69 in regard to promoting inclusive political institution in postEuromaidan Ukraine. Further research could employ the chosen analytical framework and apply it to the comparative studies of civil society inclusion to regional public administration across Ukraine.

\section{Bibliography}

Acemoglu, Daron and James Robinson. "Paths to Inclusive Political Institutions." January 12, 2016. Accessed May 31, 2017. https://economics.mit.edu/files/11338.

69 Acemoglu, "Ukraine's Legacy of Serial Oligopoly." 
Acemoglu, Daron and James Robinson. Why Nations Fail: The Origins of Power, Prosperity, and Poverty. New York: Crown Publishers, 2012.

Acemoglu, Daron. "Ukraine's Legacy of Serial Oligopoly." The Globe and Mail, March 14, 2014. Accessed May 31, 2017. http://www.theglobeandmail.com/opinion/ukrainians-needinclusion-not-extraction/article17481308/.

Boldrin, Michele, David Levine and Salvatore Modica. "Review of Acemoglu and Robinson's Why Nations Fail." September 2012. Accessed May 31, 2017. http://blogs.exeter.ac.uk/ insted/2013/o4/og/why-nations-fail-the-origins-of-power-prosperity-and-poverty/.

Dahl, Robert. Democracy and Its Critics. New Haven; London: Yale University Press, 1989.

Database "Political Elites of Ukrainian Regions." Accessed May 31, 2017. http://src-h.slav.hokudai. ac.jp/ukrregions/titulna.html.

Decree of the Head of Luhansk Military-Civil Administration No. 173 "On the Additional Instructions regarding Limiting the Move of Vehicles across the Line of Separation of the Sides." May 12, 2015. Accessed May 30, 2017. http://ipress.ua/media/gallery/full/4/c/4cc78d 83af93f9e8af3cef59719a68oe.jpg.

Garaz, Stela. 'Exploring the Link between Power Concentration and Ethnic Minorities' Mobilization in Post Soviet Georgia, Moldova, and Ukraine." PhD diss., Central European University, 2012.

Grytsenko, Oksana. “A Look at Life in Luhansk Oblast's 'Tinderbox' with Region's Leader." Kyiv Post+, November 14, 2014. Accessed on March 31, 2017. https://www.kyivpost.com/article/ content/war-against-ukraine/a-look-at-life-in-luhansk-oblasts-tinderbox-with-regionsleader-371768.html.

Grytsenko, Oksana. "Lucrative Trade in War Zone Persists despite Blockade that Tries to Stop it." Kyiv Post, March 9, 2017.

Jeffery, Charlie and Daniel Wincott. “The Challenge of Territorial Politics: Beyond Methodological Nationalism." In New Directions in Political Science: Responding to the Challenges of an Interdependent World, edited by Hay Colin, 167-88. New York: Palgrave Macmillan, 2010.

"Holova Luhanskoi oblasnoi viiskovo-tsivilnoi administratsii Hennadii Moskal zvernuvsia do Ministra VSU, nachalnyka Heneralnoho shtabu ZSU, sekretaria RNBO Ukrainy, shchob rozzbroity bataliony 'Tornado' i 'Chernihiv' [The Head of Luhansk Military-Civil Administration Hennadii Moskal Addressed the Minister on Military Affairs, the Head of the General Headquarters of the Ukrainian Army, Secretary of the National Security and Defense Council and asked them to disarm the battalions 'Tornado' and 'Chernihiv']." Luhansk Military-Civil Administration Official Website, June 18, 2015. Accessed May 31, 2017. http://www.loga.gov.ua/oda/press/news/golova-luganskoyi-oblasnoyi-viyskovo-civilnoyiadministraciyi-gennadiy-moskal.

"Hubernator Luhanshchyny o blockade ORDLO [Regional Governor of Luhansk Oblast Talks about the Blockade of the Areas of Luhansk Oblast Temporarily beyond the Government Control]." Liga.Novosti, January 26, 2017. Accessed May 30, 2017. http://news.liga.net/ news/politics/14679271-gubernator_luganshchiny_o_Blockade_orlo_tets_ostanutsya_bez_ topliva.htm. 
Huntington, Samuel. Political Order in Changing Societies. New Haven; London: Yale University Press, 1968.

Holotiuk, Iryna. “Heorgii Tuka: 'Ne vizhu ni chisto voennogo, ni chisto diplomaticheskogo resheniia konflikta na Donbasse.' ["Heorgii Tuka: 'I See no Purely Military, no Purely Diplomatic Solution to the Conflict in Donbas']." Fakty, April 29, 2016. Accessed May 31, 2017, http:// fakty.ua/216188-georgij-tuka-ne-vizhu-ni-chisto-voennogo-ni-chisto-diplomaticheskogoresheniya-konflikta-na-donbasse-dumayu-on-zatyanetsya-na-neskolko-let.

Kuryshko, Diana. "Yak mobilni hrupy boriutsia z kontrabandoyu v ATO [How Do Mobile Groups Fight Smuggling during the Security Operation].” BBC Ukraine, September 23, 2015. Accessed May 31, 2017. http://www.bbc.com/ukrainian/society/2015/og/150921_ato_smuggling_dk.

Latsyba, Maksym. Government Policy and the Level of Development of Civil Society in Ukraine. Kyiv: Ukrainian Centre for Independent Political Research, 2006.

"Lutsenko: Ekonomichna Blokada 'DNR/LNR' Neobhidna [Lutsenko: The Economic Blockade of 'DPR/LPR' is Necessary]." BBC Ukraine, June 8, 2015. Accessed May 30, 2017. http://www. bbc.com/ukrainian/politics/2015/o6/1506o8_lutsenko_ie_donbass_economic_blockade_sd.

Maksymov, Serhii. "Novyi hibernator Luhanshchiny podigryvaet OppoBloku — sluchainost ili zakonomernost? [New Regional Governor in Luhansk Oblast Helps OppoBlockFortuitousness or Pattern?]." Obozrevatel, May 30, 2016. Accessed May 31, 2017. https://www. obozrevatel.com/blogs/82094-novyij-gubernator-luganschinyi-podyigryivaet-oppoBlockusluchajnost-ili-zakonomernost.htm.

Kimitaka Matsuzato. "From Communist Boss Politics to Post-Communist Caciquismo: The Meso-Elite and Meso-Governments in Post-Communist Countries." Communist and PostCommunist Studies 34 (2001): 175-201.

Miles, Matthew and Michael Huberman. Qualitative data analysis: an expanded sourcebook. London: Sage Publications, 1994.

"Moskal pryznachyv sluzhbove rozsliduvannia z pryvodu zatrymanyh vahoniv batalyonom 'Tornado' [Moskal Initiated an Investigation in regard to Tornado's Act of Blocking Coaches].” Luhansk Military-Civil Administration Official Website, June 18, 2015. Accessed May 31, 2017. http://www.loga.gov.ua/oda/press/news/moskal-priznachiv-sluzhbove-rozsliduvannya-zprivodu-zatrimanih-vagoniv-batalyonom.

National and International Mechanisms of Funding Civil Society. International Practices on Confidence-Building Measures between the State and Civil Society. Accessed May 31, 2017. http://www.osce.org/ukraine/86185?download=true.

"Novyi povorot v dele ob ubiistve Endriu [A New Turning Point in Andrew's Murder]." Comments. ua, January 14, 2017. Accessed July 31, 2017. https://comments.ua/society/571547-noviypovorot-dele-ubiystve-endryu.html.

OSCE Special Monitoring Mission to Ukraine. Civil Society and the Crisis in Ukraine: Thematic Report. March 4, 2015. Accessed May 31, 2017. http://www.osce.org/ukrainesmm/141046?download=true.

OSCE Special Monitoring Mission to Ukraine. Latest from OSCE Special Monitoring Mission (SMM) to Ukraine, Based on Information Received as of 19:30, July 17, 2016. Accessed July 20, 2017, http://www.osce.org/uk/ukraine-smm/254811. 
"Prezydent ta volontery hotuiut nastup na koruptsiiu ta kontrabandu v zoni ATO [President and Volunteers Get Ready to Fight Corruption and Smuggling in the Areas where the ATO Takes Place]." President of Ukraine Petro Poroshenko Official Website, July 6, 2015. Accessed May 20, 2017, http://www.president.gov.ua/news/prezident-ta-volonteri-gotuyut-nastupna-korupciyu-ta-kontra-35610.

Robinson, James. "Why Region Fail: The Mexican Case." April 16, 2013. Accessed May 31, 2017. https://scholar.harvard.edu/jrobinson/presentations/why-regions-fail-mexican-case.

Ringis, Anastasiya. "Kontrabandisty vs. volontery. Komu meshaiut mobilnye hruppy po borbe s kontrabandoi? [Smugglers vs. Volunteers. Whom do Mobile Groups for Fighting Smuggling Disturb?]." Ukrainska Pravda, September 9, 2015. Accessed May 20, 2017. http://www.pravda. com.ua/rus/articles/2015/og/9/7080668/.

Sasse, Gwendolyn. "The 'New' Ukraine: A State of Regions." Regional and Federal Studies 11.3 (2001): 69-100.

Tuka, Heorgii. "Vybory. Pershyi dosvid [The Election. The Very First Experience]." Censor.net, Tuka's Blog, October 26, 2015. Accessed May 31, 2017. https://censor.net.ua/blogs/1135/ vibori_pershiyi_dosvd_quotzserediniquot.

Weber, Max. Economy and Society: An Outline of Interpretive Sociology. Berkley: University of California Press, 1978 [1921].

\section{(7)}

Since 2014 Dr. Valentyna Romanova has been working as a Senior Expert at the Institute for Strategic Research "New Ukraine". Since 2013 Valentyna has been co-convening "EU Foreign and Security Policy" (MA) at the National University of Kyiv-Mohyla Academy, Ukraine. Since 2012 Romanova has been an Elections Reports Editor at an international peer-review journal Regional and Federal Studies (RFS) and has recently become a co-editor of an Annual Special Issue on Regional Elections at RFS.

\section{Acknowledgements}

I am grateful to Dr. Borys Dodonov who introduced the concept of inclusive versus extractive political institutions to me. I benefited from the discussion on the previous version of this manuscript with Dr. Ekaterina Braginsky. I am grateful to a journalist of Kyiv Post magazine Oksana Grytsenko who shared her helpful comments and suggestions on the empirical part of this study. Above all, I am mostly indebted to Olena Podolian for insightful discussions of the manuscript, her constructive suggestions and methodological feedback. 